\title{
HUBUNGAN PERILAKU 3M PLUS DENGAN KEJADIAN DEMAM BERDARAH DENGUE (DBD)
}

\section{M PLUS BEHAVIOR WITH EVENT DENGUE HEMORRHAGICFEVER (DHF)}

\section{Supriyadi Periatama ${ }^{\text {* }}$ \\ Rizki Muji Lestari ${ }^{2}$ \\ Dita Wasthu Prasida ${ }^{3}$}

*I23STIKes EKA HARAP, Palangka

*email:

supriyadiferiatama022@gmail.com

\begin{abstract}
Abstrak
Latar Belakang: Penyakit Demam Berdarah Dengue (DBD) mempunyai perjalanan yang cepat dan sering fatal, karena masih banyak pasien yang meninggal akibat penanganan yang terlambat. Fenomena kasus Demam Berdarah Dengue (DBD) di Provinsi Kalimantan Tengah dilaporkan terdapat I.786 kasus, lebih banyak bila dibandingkan dengan jumlah kasus Demam Berdarah Dengue (DBD) pada tahun 2018 sebanyak 2.222 kasus, dengan jumlah kematian pada tahun 2019 sebanyak 44 orang, lebih rendah bila dibandingkan dengan jumlah kematian pada tahun 2018 sebanyak 22 orang.

Tujuan: Tujuan pada penelitian ini untuk mengetahui "Hubungan Perilaku 3M Plus Dengan Kejadian Demam Berdarah Dengue (DBD)".

Metode: Metode penelitian ini menggunakan metode studi kepustakaan atau literatur review. Tenik penelitian ini terdapat 6 jurnal yang sudah di Screening dengan kriteria inklusi mulai dari jumlah Sample 40-138 responden, dengan 2 studi design yaitu Cross Sectional dan Case Control, tahun terbit jurnal 2017-202I dan menggunakan bahasa Indonesia.

Hasil: Berdasarkan hasil penelitian menggunakan Literature Review dari 6 jurnal yang di analisis didapatkan perilaku 3M Plus responden kategori dominan baik dan Kejadian Demam Berdarah Dengue (DBD) responden kategori dominan tinggi dan hasil Statistik jurnal $p=$ value 0,05 ada hubungan perilaku 3M Plus dengan Kejadian Demam Berdarah Dengue (DBD).

Kesimpulan: Hasil analisis dari 6 jurnal penelitian Literature Review bahwa semakin tinggi perilaku 3M Plus pada kejadian Demam Berdarah Dengue (DBD) dan menunjukan bahwa ada hubungan yang sangat bermakna antara perilaku $3 \mathrm{M}$ Plus dengan kejadian Demam Berdarah Dengue (DBD).
\end{abstract}

\begin{abstract}
Background: Dengue Hemorrhagic Fever (DHF) has a fast course and is often fatal, because there are still many patients who die due to late treatment. The phenomenon of cases of Dengue Hemorrhagic Fever (DHF) in Central Kalimantan Province was reported to have 1,786 cases, more when compared to the number of cases of Dengue Hemorrhagic Fever (DHF) in 2018 as many as 2,222 cases, with the number of deaths in 2019 as many as 44 people, lower if compared to the number of deaths in 2018 as many as 22 people.

Objective: Thepurpose of this study was to determine the "Relationship of $3 \mathrm{M}$ Plus Behavior with the Incidence of Dengue Hemorrhagic Fever (DHF)".

Methods: This research method uses a literature study ormethod literature review. The technique of this research is that there are 6 journals that have been screened withcriteria inclusion ranging from a sample of 40-138 respondents, with 2 study designs namely Cross Sectional and Case Control, the journal published in 20172021 and using the Indonesian language.

Results: Based on the results of research using Literature Review of 6 journals in behavioral analysis reveals the dominant category of respondents Plus $3 \mathrm{M}$ good and Genesis Dengue Hemorrhagic Fever (DHF) respondents dominant category is high and the results of the journal Statistics $p=$ value

0.05 no relationship with the behavior of the $3 M$ Plus The incidence of Dengue Hemorrhagic Fever (DHF).

Conclusion: The results of the analysis from 6 research journals Literature Review that the higher the behavior of $3 \mathrm{M}$ Plus in the incidence of Dengue Hemorrhagic Fever (DHF) and shows that there is a very significant relationship between the behavior of $3 \mathrm{M}$ Plus and the incidence of Dengue Hemorrhagic Fever (DHF).
\end{abstract}




\section{PENDAHULUAN}

Penyakit Demam Berdarah Dengue (DBD) merupakan salah satu masalah kesehatan masyarakat di Indonesia yang jumlah penderitanya cenderung meningkat, dan penyebarannya semakin luas terutama menyerang anak-anak, serta sering menimbulkan Kejadian Luar Biasa (KLB) dan kematian. Hal ini disebabkan karena masih banyak daerah endemik yang merupakan sumber penyebaran penyakit. Penyakit Demam Berdarah Dengue (DBD) mempunyai perjalanan yang cepat dan sering fatal, karena masih banyak pasien yang meninggal akibat penanganan yang terlambat. (Widoyono, 20II). Demam Berdarah Dengue (DBD) merupakan penyakit berbahaya berbasis lingkungan yang hingga saat ini masih menjadi permasalahan kesehatan dunia. Demam Berdarah Dengue (DBD) adalah penyakit menular yang disebabkan oleh infeksi virus melalui perantara vektor Aedes aegypti dan Aedes albopictus. (Saputri et al., 2020). Menurut data yang diperoleh dari Dinas Kesehatan Provinsi Kalimantan Tengah (Dinkes) tahun 2019, kasus Demam Berdarah Dengue (DBD) di Provinsi Kalimantan Tengah dilaporkan terdapat 1.786 kasus, lebih banyak bila dibandingkan dengan jumlah kasus Demam Berdarah Dengue (DBD) pada tahun 2018 sebanyak 2.222 kasus, dengan jumlah kematian pada tahun 2019 sebanyak 44 orang, lebih rendah bila dibandingkan dengan jumlah kematian pada tahun 2018 sebanyak 22 orang. Incidence Rate/Angka Kesakitan pada tahun 2019 sebesar 66,9 per 100.000 penduduk lebih sedikit bila dibandingkan dengan angka kesakitan pada tahun 2018 sebesar 83.5 per 100.000 penduduk dan Fatality Rate/Angka Kematian pada tahun 2019 sebesar 2.5\% lebih tinggi bila dibandingkan tahun 2018 sebesar $1 \%$. Kasus Demam Berdarah Dengue (DBD) di kota Palangka Raya menunjukkan angka kesakitan mencapai 34,2 per 100.000 penduduk, kedua menunjukkan angka kesakitan di kabupaten Barito Timur mencapai I3,4 per 100.000 penduduk. (Dinkes Provinsi Kalteng, 2019) Angka ini menjadi perhatian oleh Dinkes
Provinsi Kalimantan Tengah, sehingga upaya-upaya untuk menanggulangi perkembangbiakkan jentik nyamuk Aedes aegypti penyebab Demam Berdarah Dengue (DBD) di rumah-rumah penduduk menjadi ketat dilaksanakan. Dinkes Provinsi Kalimantan Tengah bekerjasama dengan Puskesmas Menteng menemukan kasus Kejadian Luar Biasa (KLB) Demam Berdarah Dengue (DBD) di komplek perumahan di wilayah kerja Puskesmas Menteng, dimana dalam satu rumah tangga diketahui semua anggota keluarga terserang DBD. Berdasarkan hasil observasi di komplek perumahan $\mathrm{Jl}$. G.Obos XII yang merupakan lokasi KLB Demam Berdarah Dengue (DBD), diketahui bahwa drainase rumah tangga di lingkungan tersebut kurang baik, sehingga apabila terjadi hujan lebat terus-menerus maka air akan meluap hingga masuk ke beberapa rumah penduduk. Selain itu, faktor perilaku juga menjadi salah satu penyebabnya, karena masih cukup banyak warga yang tidak memeperhatikan wadah terbuka yang berpotensi sebagai tempat hidup nyamuk Aedes aegypti. (Ardina et al., 2018)

Demam Berdarah Dengue (DBD) merupakan penyakit yang meresahkan di masyarakat karena dapat berakibat fatal seperti kematian. Demam Berdarah Dengue (DBD) ditularkan ke manusia melalui gigitan nyamuk Aedes aegypti yang terinfeksi virus Dengue. Pada tahun 2016 Target Renstra Kementerian Kesehatan untuk angka kesakitan Demam Berdarah Dengue (DBD) tahun 2016 sebesar $<49$ per 100.000 penduduk, dengan demikian Provinsi Kalimantan Tengah terutama kota Palangka Raya belum mencapai target yang telah ditetapkan Kementerian Kesehatan. (Ardina et al., 2018) Berdasarkan kajian dari Kementerian Kesehatan RI, Kejadian Luar Biasa (KLB) Demam Berdarah Dengue (DBD) di Indonesia diakibatkan oleh beragam faktor. Pertama, pada dasarnya penyakit menular termasuk Demam Berdarah Dengue (DBD) masih endemik di beberapa wilayah karena terdapat vektor nyamuk hampir di seluruh pelosok tanah air serta adanya 4 sel tipe virus yang bersirkulasi sepanjang 
tahun. Faktor kedua adalah lemahnya sistem kewaspadaan dini sehingga penanganan dan pengobatan kasus sebagai intervensi belum dilakukan sebagaimana mestinya. Ketiga, kemudahan alat transportasi memungkinkan pergerakan/perpindahan alat angkut, penumpang, bahan/barang, dan alat dari satu wilayah ke wilayah lain yang merupakan daerah endemik. Ketiga faktor tersebut didukung dengan masih rendahnya kesadaran masyarakat akan paradigma hidup sehat dan kesadaran pada kondisi lingkungan sekitar sebagai faktor risiko penyebaran penyakit Demam Berdarah Dengue (DBD). (Ardina et al., 20।8)

Deman Berdarah Dengue (DBD) adalah penyakit yang disebabkan oleh infeksi virus dengue melalui gigitan nyamuk Aedes aegypti. Demam dengue merupakan penyakit akibat gigitan nyamuk yang berkembang paling pesat di dunia. Menurut Word Health Organization (WHO). Hal ini dikaitkan dengan kenaikan temperatur yang tinggi dan perubahan musim hujan dan kemarau disinyalir menjadi faktor resiko penularan virus dengue. Pada tahun 2005 mulai dilaporkan adanya kasus Demam Berdarah Dengue (DBD) di Kabupaten Banjarnegara yang terdiri dari daerah perkotaan 12 kelurahan dan perdesaan yang meliputi 253 desa. Jumlah kasus Demam Berdarah Dengue (DBD) di Desa Wanadri wilayah kerja Puskesmas Bawang 2, Kabupaten Banjarnegara pada bulan Januari 2016 sebanyak 45 orang dengan I orang meninggal akibat kasus tersebut (data Puskesmas Bawang 2 Desa Wanadri Kabupaten Banjarnegara). Vektor Demam Berdarah Dengue (DBD) yang paling utama adalah nyamuk Aedes aegypti. Aedes akan berkembangbiak pada air yang tergenang dan tidak beralaskan tanah. Aedes dapat bertelur sebanyak 100-200 telur setiap kali bertelur, Perkembangan telur hingga menjadi nyamuk Aedes dewasa membutuhkan waktu 7-10 hari. Penelitian sebelumnya yang dilakukan di Kabupaten Bantul oleh Puspaningrum (2014) tentang hubungan 3M terhadap Demam Berdarah Dengue (DBD). Studi tentang peningkatan derajat kesehatan dari kejadian
Demam Berdarah Dengue (DBD) masih kurang di lakukan, bahkan di kabupaten banjarnegara sampai saat ini belum pernah ada yang mengkaji. Studi pendahuluan yang telah dilakukan terhadap 50 orang responden didapatkan 33 orang responden (66\%) di wilayah kerja Puskesmas Bawang 2, Kecamatan Bawang Kabupaten Banjarnegara yang tidak melaksanakan kegiatan praktik Pemberantasan Sarang Nyamuk (PSN) dengan baik dan benar semoga dengan dengan penelitian ini kedepan Perilaku PSN dapat dilakukan dengan baik.(Suseno \& Retna, 2019)

Penelitian ini adalah observasional analitik dengan rancangan cross sectional. Dalam penelitian ini peneliti mencari hubungan antara variabel bebas faktor risiko yaitu perilaku 3M plus masyarakat dengan variabel terikat (efek) yaitu kejadian Demam Berdarah Dengue (DBD) dan pengukurannya dilakukan pada saat yang bersamaan. Penelitian ini dilaksanakan di wilayah kerja Puskesmas Gambirsari Surakarta pada tanggal 2 Desember 2014 sampai dengan Juni 20I5. Populasi target dalam penelitian ini adalah semua masyarakat di wilayah kerja Puskesmas Gambirsari Surakarta RT 09 RW 20 Kelurahan Kadipiro Populasi aktual dalam penelitian ini adalah semua masyarakat di wilayah kerja Puskesmas Gambirsari Surakarta RT 09 RW 20 Kelurahan Kadipiro sebanyak 213 orang. Sampel dalam penelitian ini adalah masyarakat di wilayah kerja Puskesmas Gambirsari Surakarta (RT 09 RW 20 Kelurahan Kadipiro) sebanyak 138 orang. Teknik pengambilan sampel yang digunakan adalah simple random sampling dengan cara mengundi anggota populasi. Kriteria inklusi pada penelitian ini adalah masyarakat yang berdomisili di RT 09 RW 20 Kelurahan Kadipiro, masyarakat yang sehat jasmani maupun rohani, dan masih hidup sedangkan kriteria eksklusi pada penelitian ini adalah tidak bersedia untuk mengisi kuesioner dan tidak berada di rumah saat penelitian dilakukan. Cara pengambilan data dalam penelitian ini menggunakan data primer melalui kuesioner yang diberikan kepada responden sebagai 
instrumen yang digunakan untuk mengukur perilaku $3 \mathrm{M}$ plus masyarakat. Cara pengambilan data dalam penelitian ini juga menggunakan data sekunder melalui studi pendahuluan di wilayah kerja Puskesmas Gambirsari Surakarta untuk mengetahui jumlah kejadian Demam Berdarah Dengue (DBD) pada tahun 20I4. Teknik analisis yang digunakan adalah uji Pearson pada tingkat kesalahanatau $\alpha$ sebesar 5\% dengan bantuan program SPSS versi 18.

Penelitian ini berbanding terbalik dengan Penelitian Lukman dan Windi (2013) yang berjudul "Pengetahuan Dan Perilaku Masyarakat Terhadap Demam Berdarah Dengue (DBD) di Kecamatan Batulicin Kabupaten Tanah Bumbu Provinsi Kalimantan Selatan”. Hasil uji korelasi menggunakan ChiSquare diperoleh nilai sig sebesar 0,016<0,05 yang artinya terdapat hubungan yang signifikan antara perilaku terhadap kejadian Demam Berdarah Dengue (DBD) di Dusun Branjangan, Tijayan, Manisrenggo, Klaten. Hal tersebut dapat diasumsikan karena latar belakang pengetahuan yang kurang baik akan diikuti oleh perilaku yang kurang baik dalam menanggapi terjadinya penyakit Demam Berdarah Dengue (DBD) demikian juga dengan kurangnya inisiatif dari masyarakat untuk menjaga dan memelihara lingkungan sekitarnya sehingga mengakibatkan terjadinya penyakit dan memudahkan penularannya kepada orang sehat. Tindakan pencegahan meluasnya penyakit Demam Berdarah Dengue (DBD) dilakukan dengan pengendalian terhadap vektor melalui pemberantasan jentik nyamuk Aedes aegypti dengan beberapa metode yang tepat yaitu secara fisik, biologis dan kimiawi. Metode ini apabila dikombinasikan dengan perilaku menguras, menutup dan memanfaatkan/mendaur ulang barang bekas (3M) akan menjadi cara yang efektif dalam mencegah penyakit Demam Berdarah Dengue (DBD). (Fauziah et al., 2019).

Gerakan pemberantasan sarang nyamuk dengan melakukan 3M Plus (PSN Plus) ini sangat efektif dibanding dengan metode pencegahan Demam
Berdarah Dengue (DBD) yang lain karena Gerakan PSN Plus menghilangkan sarang tempat nyamuk Aedes aegypti bertelur sehingga tidak memberikan kesempatan nyamuk Aedes aegypti sebagai vektor demam berdarah untuk melanjutkan siklus kehidupan dari mulai telur, jentik, pupa, dan nyamuk dewasa atau tidak memberikan kesempatan untuk berkembang biak (Gifari, 2017). Menurut tenaga kesehatan memberi penyuluhan terhadap masyarakat seperti penyuluhan tentang air bersih, air kotor, rumah sehat dan pembersih sarang nyamuk. Berdasarkan data diatas peneliti ingin mereview dan menganalisis beberapa jurnal yang meneliti tentang Hubungan Perilaku 3M Plus Dengan Kejadian Demam Berdarah Dengue (DBD).

\section{METODOLOGI}

Metode penelitian pada dasarnya merupakan cara ilmiah untuk mendapatkan data dengan tujuan dan kegunaan tertentu. Untuk mencapai tujuan yang diperlukan dan dibutuhkan metode yang relevan untuk mencapai tujuan yang diinginkan. (Sugiyono, 2016) .

Dalam penelitian ini, penulis menggunakan metode studi kepustakaan atau literatur review.

Desain penelitian ini dilakukan dengan pendekatan cross-sectional dan case-control. Penelitian cross-sectional dan case-control adalah suatu penelitian untuk mempelajari dinamika korelasi antara faktor-faktor risiko dengan efek, dengan cara pendekatan, observasional, atau pengumpulan data. Penelitian crosssectional dan case-control hanya mengobservasi sekali saja dan pengukuran dilakukan terhadap variabel subjek pada saat penelitian (Notoatmojo, 20I0). Judul dalam penelitian ini adalah "Hubungan Perilaku 3M Plus Dengan Kejadian Demam Berdarah Dengue (DBD)”. Variabel independen "perilaku 3 M plus dengan kejadian demam berdarah dengue (DBD)" dan variabel dependen "perilaku 3M plus dan demam berdarah dengue (DBD)". 


\section{HASIL DAN PEMBAHASAN}

Hasil analisis dari 6 jurnal berdasarkan perilaku 3M Plus didapatkan dominan kategori baik sebanyak 381 responden $(63,5 \%)$ dan kejadian Demam Berdarah Dengue (DBD) didapatkan dominan tinggi dengan responden sebanyak 347 (57,8\%). Berdasarkan hasil penelitian literature review dari 6 jurnal terdapat hubungan yang signifikan antara perilaku 3M Plus dengan kejadian Demam Berdarah Dengue (DBD) dengan hasil $\mathrm{p}$-value $=<0,005$.

\section{KESIMPULAN}

Hasil ditelaah artikel penelitian yang dilakukan oleh peneliti mengenai hubungan perilaku $3 \mathrm{M}$ Plus dengan kejadian Demam Berdarah Dengue (DBD) peneliti mendapatkan hasil dari 6 jurnal berdasarkan perilaku $3 \mathrm{M}$ Plus didapatkan dominan kategori baik sebanyak $38 \mathrm{I}$ responden (63,5\%) dan kejadian Demam Berdarah Dengue (DBD) didapatkan dominan tinggi dengan responden sebanyak $347 \quad(57,8 \%)$ dan peneliti simpulkan terdapat hubungan yang signifikan antara perilaku 3M Plus dengan kejadian Demam Berdarah Dengue (DBD) dengan hasil $\mathrm{p}$-value $=<0,005$. Perilaku 3M Plus yang baik disebabkan karena beberapa faktor antara lain: tingkat pendidikan semakin tinggi pendidikan seseorang maka semakin mudah seseorang menerima informasi dan sikap dari diri seseorang yang bertindak melakukan tindakan yang baik dalam kehidupan sehari-hari seperti penerapan 3M Plus.

\section{REFERENSI}

I. Saputri, R., Indah, M. F., \& Ariyanto, E. (2020). Hubungan Perilaku 3M Plus Pendidikan Dan Pekerjaan Dengan Kejadian Demam Berdarah Dengue Di Wilayah Kerja Puskesmas Bati-Bati Kabupaten Tanah Laut. dbd 2

2. Profil Kesehatan Indonesia. (2019). Kementrian Kesehatan Republik Indonesia (KEMENKES RI). 2019. Data dan Informasi Profil Kesehatan Indonesia 2018. Jakarta: Ditjen P2P, Kemenkes RI
2019. In Journal of Chemical Information and Modeling (Vol. 53, Issue 9).

3. Ardina, R., Purbayanti, D., \& Sartika, F. (20/8). Rinny Ardina, Nurhalina, Suratno, Dwi Purbayanti, Fera Sartika, Agus, Survey Jentik Nyamuk Aedes Aegypti. 55-61. file:///C:/Users/USER/Downloads/258643-surveijentik-nyamuk-aedes-aegypti-di-pe-b5da4e0f.pdf

4. Dinkes Provinsi Kalteng. (2019). Dinas Kesehatan Provinsi Kalimantan Tengah. Dinas Kesehatan Provinsi Kalimantan Tengah, 09. http://www.dinkes.kalteng.go.id/haldownload-.html

5. Kemenkes RI. (20I6). Kendalikan DBD Dengan PSN 3M Plus. Kontak[at]Kemkes[Dot]Go[Dot]ld. https://www.kemkes.go.id/article/view/160209000 02/kendalikan-dbd-dengan-psn-3m-plus.html

6. Suseno, B., \& Retna, R. (2019). Hubungan Perilaku Pemberantasan Sarang Nyamuk Terhadap Kejadian Demam Berdarah Dengue (DBD) Di Banjarnegara. 2I-25.

7. Fauziah, N., Rahayu, U., \& Thohari, I. (2019). Perilaku 3M Bagi Penghuni Rumah Mempengaruhi Kejadian Penyakit Demam Berdarah Dengue. Gema Lingkungan Kesehatan, 17(1), 50-56. https://doi.org// 0.36568/kesling.vI7il.1053

8. Gifari. (20I7). Hubungan Tingkat Pengetahuan dan Perilaku Gerakan 3M Plus dengan Keberadaan Jentik Aedes aegypti (Vol. I). Bandung Meeting on Global Medicine \& Health (BaMGMH). 